\title{
Reproductive behavior of crossbred dairy cows grazing an intensive silvopastoral system under tropical dry forest conditions
}

\author{
[Comportamento reprodutivo de vacas leiteiras mestiças pastando um sistema silvipastoril \\ intensivo em condições de floresta tropical seca] \\ E. Sierra-Montoya ${ }^{1}$, R. Barahona-Rosales ${ }^{1}$, Z.T. Ruiz-Cortés ${ }^{2}$ \\ ${ }^{1}$ Faculty of Agricultural Sciences, Universidad Nacional de Colombia, Sede Medellín, Colombia \\ ${ }^{2}$ Faculty of Agrarian Sciences, Group of Research Biogénesis, University of Antioquia, Medellín, Colombia
}

\begin{abstract}
It is widely accepted that selection for high milk yield in dairy cows has negatively affected their reproductive performance. After calving, dairy cows experience a nutritional imbalance due to an asynchrony in the occurrence of the lactation and dry matter intake peaks. In the tropics, this situation is exacerbated due to poor quality and/ or availability of the diet. A study was carried out to describe the nutritional and reproductive behavior of two-to-four parturition crossbred cows (Gyr (Bos indicus) x Holstein (Bos taurus)) divided in two groups according to their calving to first service interval (CFSI): Group 1: $\leq 50$ days CFSI, n=7; Group 2: $\geq 50$ days CFSI, $\mathrm{n}=8$. Animals were grazing in an intensive silvopastoral system (ISS) based on Leucaena leucocephala and Cynodon plectostachyus and also received protein, energy and mineral supplementation. Dry matter (DMI) and nutrient intake were individually estimated and correlations between reproductive and nutritional parameters were performed. Additionally, serum progesterone concentration was monitored. Group 2 had greater forage and total DMI and milk production than Group $1(\mathrm{P}<0.05)$. Hence, Group 2 had greater nutrient intake from forages than Group $1(\mathrm{P}<0.05)$. Group 1 had a positive nutritional balance and an optimum reproductive performance compared to Group 2, which had a negative energy balance and lengthier days with open intervals $(\mathrm{P}<0.05)$. It was corroborated that protein and energy are required in adequate levels, to ensure that uterus undergoes involution correctly and ovarian activity starts-soon in the postpartum period.
\end{abstract}

Keywords: days open, energy balance, intake, Leucaena, nutritional management

\section{RESUMO}

$\dot{E}$ amplamente aceito que a seleção para alta produção de leite em vacas leiteiras tem interferido no seu desempenho reprodutivo. Depois do parto, um extraordinário desafio nutritivo é experimentado pelas vacas leiteiras, devido a uma assincronia entre a ocorrência do pico de lactação e a do pico de consumo de matéria seca. Este estudo foi realizado para descrever o comportamento reprodutivo de vacas mestiças de dois a quatro partos (Gyr (Bos indicus) $x$ Holstein (Bos taurus)), divididos em dois grupos, de acordo com seu intervalo parto ao primeiro serviço (IPPS): grupo 1: $\leq 50$ dias IPPS, $n=7$; grupo 2: $\geq 50$ IPPS dias, $n=8$. Os animais pastaram em um sistema silvipastoril intensivo (SSI), com base em Leucaena leucocephala e Cynodon plectostachyus, e receberam também suplementação de proteína, energia e mineral. Matéria seca (CMS) e ingestão de nutrientes foram estimadas individualmente e correlações entre parâmetros reprodutivos $e$ nutricionais foram realizadas. Além disso, a concentração de progesterona em soro foi monitorizada. Vacas do grupo 2 apresentaram maior ingestão de forragem, de dieta total e de produção total de leite do que vacas do grupo $1(P<0,05)$. Dessa forma, vacas do grupo 2 apresentaram maior consumo de nutrientes de forrageiras do que os animais do grupo $1(P<0,05)$. Vacas do grupo 1 tinham um equilíbrio nutricional positivo e um ótimo desempenho reprodutivo em relação ao grupo 2, que teve um balanço energético negativo e mais longos intervalos de dias abertos $(P<0,05)$. Foi corroborado que a proteína e a energia são necessárias em níveis adequados, assim o útero sofre involução corretamente e a atividade ovariana começa logo no período pósparto.

Palavras-chave: balanço energético, dias abertos, ingestão, Leucaena, manejo nutricional

Recebido em 1 de setembro de 2015

Aceito em 29 de março de 2016

E-mail: elsierramo@unal.edu.co 


\section{INTRODUCTION}

In the tropic, bovines are frequently managed in extensive systems, in which native grasses of poor nutritional quality and production and few fodder trees are the main pasture characteristic. Most tropical grasses have high fiber content, poor digestibility, low crude protein and low soluble carbohydrate contents (Barahona and Sánchez, 2005). Dry matter intake (DMI), quality and availability of forage are important factors which affect the postpartum reproductive behavior in cattle (Hashizume et al., 2002). In the tropic, the herd has poor reproductive behavior, represented by low calving rates (50$55 \%$ ), advanced age at first parturition, and prolonged days open and calving intervals. After calving, the nutritional requirements of the dairy cow change abruptly, due to nutritional demands associated with colostrum production and lactation initiation. Usually, the cow goes through a negative energy balance (NEB) (Butler, 2000), as her energy requirements are greater than what is supplied by the diet. It has been suggested that in dairy cows, poor reproductive performance is related to the duration and extent of the NEB (Montaño and Ruiz-Cortés, 2005). In cows in NEB, there is a reduction in the circulating concentration of progesterone, which affects the fertility of the cow (Butler, 2000). There is also a reduction in blood glucose concentration, which diminishes the circulating levels of insulin, and in turn, alters the concentration of insulin-like growth factor-I and estradiol necessary for ovulation. Additionally, the NEB leads to a decline in the secretion of luteinizing hormone $(\mathrm{LH})$ increasing the days open interval and lengthening the postpartum anestrus (Butler, 2000). In turn, both a deficit and an excess of dietary protein supply would result in fertility alterations (Butler, 2000).

Successful strategies to enhance reproductive behavior include improved nutritional management through the dietary inclusion of silages, forages, supplements, additives or the adoption of agroforestry systems. One of the most promising strategies to enhance animal productivity is the use of silvopastoral systems (SS) (Cuartas et al., 2014) and this incudes improvement in herd reproductive performance (Tarazona et al., 2013). However, reproductive performance of dairy cows grazing in intensive silvopastoral systems (ISS) based on the legume
Leucaena leucocephala has not been fully studied as of yet. This study was carried out to compare the reproductive performance of dairy cattle grazing in a tropical dry forest ISS and relate it to dry matter and nutrient intake, nutritional balance, body weight, milk production, and serum progesterone levels.

\section{MATERIALS AND METHODS}

The study was conducted at Hacienda El Chaco, Piedras municipality, Tolima State, Colombia (04'29'06,7' 'North and 74'59'5,4' West). This farm is located at 605 m.a.s.l and has annual rainfall between $250-1800 \mathrm{~mm}$, a relative humidity of $70+9,3 \%$ and a mean temperature of $26^{\circ} \mathrm{C}$. Its life zone corresponds to tropical dry forest (Holdridge et al., 1971).

Animals evaluated were F1: Bos indicus x Bos Taurus (Gyr x Holstein) cows with an average body weight (BW) of $480 \mathrm{~kg}$, two to four parturitions and an average age of 5.65 years. Cows were categorized into two groups: those with first service before 50 d postpartum $(n=7)$ (group 1) and those with first service after $50 \mathrm{~d}$ postpartum $(\mathrm{n}=8)$ (group 2). Before weaning, all cows nourished their calves with colostrum during 4-5 days. Cows were milked twice daily using a mechanical milking machine, lactancy lasted 305 days and annual average milk production was $10 \mathrm{~kg}$ day $^{-1} \mathrm{cow}^{-1}$.

Cows grazed in an ISS, composed of 7000 to 10000 shrubs/hectare the browse legume Leucaena leucocephala and the grass Cynodon plectostachyus, plus timber trees (Azadirachta indica, Albizia guachapele and Tectonia grandis), planted every $30 \mathrm{~m}$ along the ISS. Water was available ad libitum in each ISS paddock. Cows were assigned every $24 \mathrm{~h}$ to a new grazing strip $\left(2000-3000 \mathrm{~m}^{2}\right)$ and were accompanied by a sire for natural mating. Each paddock was allotted a recovery period of 38 days. At the milking parlor, the cows were supplemented $\left(\mathrm{kg} \mathrm{DM} \mathrm{d}^{-1} \mathrm{cow}^{-1}\right)$ with rice (Oriza sativa) flour $(1.5 \mathrm{~kg})$, commercial concentrate $(2.6 \mathrm{~kg})$ equally divided between the two daily milkings and corn silage $(1.2 \mathrm{~kg})$ in the afternoon milking. Animals were also offered mineral salt $\left(120 \mathrm{~g} \mathrm{cow}^{-1}\right)$. Stocking rate was $4.46 \mathrm{AU} / \mathrm{ha}$ (AU $=$ Animal Unit $=$ one animal of $450 \mathrm{~kg}$ of $\mathrm{BW}$ ) and the grazing pressure of the ISS was $12.1 \mathrm{~kg}$ of DM per $100 \mathrm{~kg}$ of BW. 
Samples of C. plectostachyus, and $L$. leucocephala were collected at different moments during the experimental period (AgSept-Nov-Dec 2012 and Jan-Feb 2013). Each time, one $\mathrm{kg}$ of fresh matter was collected, weighted, pre-dried in a shaded space at room temperature and sent to the laboratory. Samples of supplements (rice flour, commercial concentrate and corn silage) were collected in Ag-Sept 2012. Corn silage samples were managed as described for ISS forages before sending them to the Laboratorio de Análisis Químico $y$ Bromatológico of the National University of Colombia, Medellín Campus, where the following determinations were carried out: calcium $(\mathrm{Ca})$ and phosphorous $(\mathrm{P})$ contents by atomic absorption and U.V - VIS spectrophotometry (ICONTEC,2003; ICONTEC,2001); total ash by direct incineration (AOAC, 2005); acid detergent fiber, neutral detergent fiber, ether extract (ICONTEC, 1973); crude protein (CP) by Kjeldahl (ICONTEC,1999) and gross energy (ISO, 1998).

Forage intake was estimated based on Haydock and Shaw (1975). Supplement intake was estimated as the difference between offered and refused individual feeds. The nutritional balance (NB) was estimated using the program CNCPS Version 5.0.4 taking into account animal breed age, body weight, reproductive parameters, production data (daily milk production, fat and protein content in milk) environmental conditions and nutritional quality and intake of each feedstuff. Intake of nutrients (CP, GE, Ca, P and NDF) was calculated from intake of forages and supplements and their chemical composition. Both DMI and nutrient intake were compared for both groups of cows to determine nutrient limitations at the postpartum period.

Cows were monitored twice a day (AM-PM), as they moved to the milking parlor. Reproductive events such as services, estrus detected by the sire or first heat post-calving and parturitions were registered. Reproductive parameters such as days open (DO), calving interval (CI), calving to first service interval (CFSI), services per conception $(\mathrm{S} / \mathrm{C})$ were recorded during 8 months (June 2012-February 2013).
Pregnancy confirmation was carried out by rectal ultrasonography about 45 days after first service. Coccygeal vein blood samples were collected twice a week after parturition until the pregnancy was confirmed in vacuum tubes without anticoagulant (Vacutainer () ). These samples were centrifuged (3000 rpm for 20 minutes) to obtain serum, two $\mathrm{ml}$ of which were packaged in Eppendorf ${ }^{\circledR}$ tubes and kept at $-4^{\circ} \mathrm{C}$ until analyzed for progesterone content $(\mathrm{ng} / \mathrm{ml})$ at the Hormone Laboratory of the National University of Colombia, Bogotá campus (commercial kit DS-EIA-Steroid_Progesterone). The sensibility of the kit was $0 . \overline{4} \mathrm{ng} / \mathrm{ml}$. For each variable, data normality was evaluated through the ShapiroWilk test, and homoscedasticity was assessed through the Levene test. An unbalanced completely randomized design was used to evaluate the reproductive performance (DO, CFSI, CI, and S/C), nutritional parameters (DMI, nutrient intake, and balance), body weight, milk production and serum progesterone of both groups of cows. One-way ANOVA was used to compare the dependent variables. Mean differences were compared with the Duncan test at an alpha of 0.05 . The relationship between variables of reproductive behavior and nutrient intake was evaluated by simple correlation. The GLM procedure of SAS version 9.1.3 (2001) was used to perform these analyses.

\section{RESULTS AND DISCUSSION}

The content of CP in L. leucocephala was high $(26 \% \pm 2.7)$, as well as its content of metabolize energy (ME; $2.62 \mathrm{Mcal} \mathrm{Kg} \mathrm{DM}^{-1}$ ) due to its low content of NDF $(28.2 \%)$, which makes it more digestible and of faster passage rates (Barahona and Sánchez, 2005; Table 1). As reported by Sierra et al., 2015 (in press), the protein content of L. leucocephala almost tripled that of $C$. plectostachyus $(9.9 \% \pm 1.7)$. In turn, there was high NDF content $(75.1 \%)$ in $C$. plectostachyus and thus, poor soluble content, which could limit the digestibility of this grass. The CP content of the diet was $14.3 \%$, doubling the minimum $(7 \%)$ $\mathrm{CP}$ requirements for growth of the ruminal bacteria needed to ferment structural carbohydrates. 
Sierra-Montoya et al.

Table 1. Chemical composition (mean and standard deviation) of dairy cattle feeds from (ISS) and supplements

\begin{tabular}{lccccc}
\hline Fraction & L. leucocephala & $\begin{array}{c}\text { C. } \\
\text { plectostachyus }\end{array}$ & Rice flour & Concentrate & Corn silage \\
\hline $\mathrm{DM}, \%$ & $20.0 \pm 2$ & $20.0 \pm 2$ & $90.2 \pm 2$ & $89.1 \pm 2$ & $35.0 \pm 2$ \\
$\mathrm{CP}, \%$ & $26.0 \pm 2.7$ & $9.9 \pm 1.7$ & $14.1 \pm 0.1$ & $18.5 \pm 0.5$ & $6.9 \pm 0.5$ \\
$\mathrm{NDF}, \%$ & $28.2 \pm 2.4$ & $75.1 \pm 1.2$ & $19.8 \pm 0.3$ & $25.5 \pm 0.8$ & $69.9 \pm 2.9$ \\
$\mathrm{ADF}, \%$ & $25.5 \pm 1.9$ & $41.7 \pm 0.7$ & $10.5 \pm 0.1$ & $15.7 \pm 1.5$ & $43.1 \pm 4.2$ \\
$\mathrm{EE}, \%$ & $1.19 \pm 0.06$ & 20.04 & 9.07 & 1.03 \\
$\mathrm{GE}, \mathrm{Mcal} / \mathrm{kg}$ & $4640 \pm 103$ & $4318 \pm 18$ & $5204 \pm 104$ & $4484 \pm 69$ & $4280+140$ \\
$\mathrm{Ash}, \%$ & $8.9 \pm 0.7$ & $9 \pm 1$ & $9.0 \pm 1.0$ & $10.8 \pm 0.3$ & $8.1 \pm 1.2$ \\
$\mathrm{Ca}, \%$ & $1.5 \pm 0.3$ & $0.3 \pm 0.04$ & $0.1 \pm 0.06$ & $2.1 \pm 0.1$ & $0.2 \pm 0.04$ \\
$\mathrm{P}, \%$ & $0.3 \pm 0.1$ & $2.0 \pm 0.1$ & $0.9 \pm 0.1$ & $0.2 \pm 0.04$ \\
$\mathrm{Cu}, \mathrm{mg} / \mathrm{Kg}$ & $21.3 \pm 15.4$ & $9.0 \pm 3.8$ & - & - & - \\
$\mathrm{Fe}, \mathrm{mg} / \mathrm{Kg}$ & $76.9 \pm 51.1$ & $184.5 \pm 79$ & - & - & - \\
$\mathrm{Mn}, \%$ & $48.0 \pm 20.7$ & $28.0 \pm 3.8$ & - & - & - \\
$\mathrm{Mg}, \mathrm{mg} / \mathrm{Kg}$ & $0.3 \pm 0.04$ & $0.1 \pm 0.01$ & - & - & - \\
$\mathrm{K}, \mathrm{mg} / \mathrm{Kg}$ & $2.2 \pm 0.4$ & $1.9 \pm 0.5$ & - & - & - \\
$\mathrm{Na}, \mathrm{mg} / \mathrm{Kg}$ & $42.1 \pm 42$ & $105.4 \pm 42$ & - & - & - \\
$\mathrm{Zn}, \mathrm{mg} / \mathrm{Kg}$ & $23.5 \pm 3.1$ & $48.7 \pm 13.4$ & - & 3.08 & - \\
$\mathrm{EM}, \mathrm{Mcal} / \mathrm{kg}$ & 2.64 & 1.90 & 3.33 & & 1.84 \\
\hline$D M \mathrm{dry} \mathrm{matter}, C P$ crude protein, $N D F$ neutral detergent fiber, $A D F$ acid detergent fiber, $E E$ ether extract, $G E$ gross \\
$\mathrm{energy.}$
\end{tabular}

It has been suggested that the inclusion of Leucaena in the diet would stimulate stargrass intake with no reproductive alterations if that inclusion is less than $30 \%$ (Martins-Maurício et al., 2009). In the present study, the intake of Leucaena in both groups of cows was around $28 \%$ (Table 2). This level of inclusion is recommended in light of the presence of mimosine and its ruminal metabolite dihydroxypyridine (2-hydroxy-3 [1H]-pyridone and 3-hydroxy-4 [1H]-pyridone3,4-DHP, a toxic, alkaloid non-protein aminoacid (El-Harith et al., 1987) that can be found at concentrations between 2.3 to $6.95 \%$ in Leucaena leaves (García et al., 2008). It is an antimitotic and alopecic agent, known to reduce DMI and to alter renal and liver function. In non-adapted animals, high mimosine intake could interfere with fertility due to early embryonary mortality (Hammond, 1995).

Table 2. Dry matter intake of dairy cows grouped by calving to first service interval (CFSI). (less than or more than 50 days)

\begin{tabular}{|c|c|c|c|c|}
\hline \multirow[t]{2}{*}{ Feeds } & \multicolumn{2}{|c|}{ Group 1: less than 50 days } & \multicolumn{2}{|c|}{ Group 2: more than 50 days } \\
\hline & $\mathrm{kg} \mathrm{DM} / \mathrm{cow} / \mathrm{d}$ & $\begin{array}{l}\% \text { of forage or } \\
\text { supplement }\end{array}$ & $\mathrm{kg} \mathrm{DM} / \mathrm{cow} / \mathrm{d}$ & $\begin{array}{l}\% \text { of forage or } \\
\text { supplement }\end{array}$ \\
\hline C. plectostachyus & $5.30 \mathrm{~b}$ & 72.01 & $6.00 \mathrm{a}$ & 71.60 \\
\hline L leucocephala & $2.06 \mathrm{~b}$ & 27.99 & $2.38 \mathrm{a}$ & 28.40 \\
\hline Total forage & $7.36 \mathrm{~b}$ & 100 & $8.38 \mathrm{~b}$ & 100 \\
\hline Comercial Concentrate & $2.50 \mathrm{a}$ & 50.40 & $2.48 \mathrm{a}$ & 49.70 \\
\hline Corn Silage & $1.12 \mathrm{a}$ & 22.58 & $1.04 \mathrm{a}$ & 20.84 \\
\hline Rice Flour & $1.34 \mathrm{a}$ & 27.02 & $1.47 \mathrm{a}$ & 29.46 \\
\hline Total suplement & $4.96 \mathrm{a}$ & 100 & $4.99 \mathrm{a}$ & 100 \\
\hline Total diet & $12.32 \mathrm{~b}$ & & $13.37 \mathrm{a}$ & \\
\hline Forage/Concentrate ratio & $2.9: 1$ & & $3.4: 1$ & \\
\hline
\end{tabular}


In this study, around 59 and $63 \%$ of the DM ingested by the cows in Group 1 and 2 respectively came from forages (7.36 and $8.38 \mathrm{~kg}$ ), and the rest $(4.96$ and $4.99 \mathrm{~kg}$ ) from supplements. In turn, L. leucocephala represented around $28 \%$ of the forage intake (2.06 and $2.38 \mathrm{~kg} \mathrm{DM})$, while the stargrass comprised approximately $72 \% \quad(5.3$ and $6 \mathrm{~kg}$ $\mathrm{DM}$ ), leading to high amounts of structural carbohydrates in both diets (Table 2). Cows in Group 1 and 2 had a DMI of 2.6 and $2.7 \%$ of $\mathrm{BW}$, respectively. Lower DMI was has been reported previously in supplemented $(2.5 \%)$ and non-supplemented (1.7\%) crossbred cows (Aguilar et al., 2009). Cows in Group 1 consumed less forage DM than Group 2 cows $(\mathrm{P}<0.05$; Table 2), with the forage/concentrate ratio being greater in Group 2 cows. This is associated to the higher nutritional requirements in Group 2 cows due to their greater milk yield. Supplement intake did not differ between both groups of cows as the farmer offered the same amount of supplement to all cows at the milking parlor.

The net energy of lactation requirements for a cow producing $15 \mathrm{~kg}$ of milk of $4 \%$ fat and $3.0 \%$ protein are $19 \mathrm{Mcal} /$ day, and required $\mathrm{CP}$ in the diet is $16.6 \%$ (NRC, 2001). In the present study, diets provided 19.2 and $20.3 \mathrm{Mcal} /$ day of net energy of lactation and 14.4 and $14.6 \%$ of $\mathrm{CP}$, suggesting that there was a positive energy balance and the need of more metabolizable protein. However, the nutritional balance estimated by means of the CNCPS, showed a positive balance of both $\mathrm{ME}(2.03 \mathrm{Mcal} / \mathrm{d})$ and MP $(202.96 \mathrm{~g} / \mathrm{d})$ in the diet of Group 1 cows, while the ME was the limiting nutrient in Group 2 cows $(0.13 \mathrm{Mcal} / \mathrm{d})$, due to their greater milk production (Table 3). Regarding $\mathrm{Ca}$ and $\mathrm{P}$, the diet provided adequate amounts of each mineral to both groups of cows, and this would contribute to adequate conception rates, estrus cycles and fertility (Roche et al., 2011). There were no differences in live weight between cows of two groups $(\mathrm{P}>0.05)$ nor daily milk production: (litters/d) 13.87 for Group 1 and 14.55 for Group 2 cows $(\mathrm{P}>0.05)$.

Most of the dietary CP (60\% and 63\%) was provided by ISS forages $(1107.9 \mathrm{~g} / \mathrm{d}$ for group 1 cows and $1266.4 \mathrm{~g} / \mathrm{d}$ for group 2 cows, respectively), with Leucaena being the greatest contributor (Table 4). Group 2 had greater intake of each nutrient from the components of the ISS compared to group $1(\mathrm{P}<0.05)$. Due to the high digestibility of the $\mathrm{CP}$ from Leucaena (around $70 \%$ ), most of this protein will be degraded in the rumen, contribute to microbial protein production and then be eventually absorbed by the cows.

Examination of the nutritional balance shows that the diet provides all necessary MP to the cows. The recommended dietary inclusion of CP for early-yielding, high yielding dairy cows grazing in tropical pastures is $180 \mathrm{~g} / \mathrm{kg} \mathrm{DM}$ (NRC, 2001). Although only $150 \mathrm{~g} / \mathrm{kg} \mathrm{DM}$ were offered in this study, there was a surplus of CP intake (Table 3). In terms of NDF, 73 and 75\% was supplied by the ISS forages for cows of group $1(4567 \mathrm{~g} / \mathrm{d})$ and group $2(5185 \mathrm{~g} / \mathrm{d})$, respectively, with stargrass being the main source. Suggested dietary NDF for high production cows grazing on tropical pastures is around $616 \mathrm{~g} / \mathrm{kg}$ DM for $(\mathrm{NRC}, 2001$ ) and in this study, cows consumed 508 and $512 \mathrm{~g} / \mathrm{kg}$ DM. Regarding gross energy intake, ISS forages provided a greater proportion to total intake than that supplied by supplements for cows in group 1 and 2 (58.5 and $61.3 \% ; 32.4$ and $36.9 \mathrm{Mcal} / \mathrm{d}$, respectively). In contrast with respect to $\mathrm{P}$ and $\mathrm{Ca}$, a greater dietary contribution came from the supplements (69.2 and 67.7\%) for cows in group 1 and 2 , respectively.

Table 3. Nutritional balance, body weight and milk production of dairy cows grouped by calving to first service interval (less than or more than 50 days)

\begin{tabular}{lcc} 
& Group 1: less than 50 days & Group 2: more than 50 days \\
\hline $\mathrm{ME}, \mathrm{Mcal} / \mathrm{d}$ & $2.03 \mathrm{a}$ & $-0.13 \mathrm{~b}$ \\
$\mathrm{MP}, \mathrm{g} / \mathrm{d}$ & $202.96 \mathrm{a}$ & $129.17 \mathrm{~b}$ \\
$\mathrm{Ca}, \mathrm{g} / \mathrm{d}$ & $16.37 \mathrm{a}$ & $13.90 \mathrm{~b}$ \\
$\mathrm{P}, \mathrm{g} / \mathrm{d}$ & $22.71 \mathrm{a}$ & $22.92 \mathrm{a}$ \\
$\mathrm{BW}, \mathrm{kg}$ & $472.4 \mathrm{a}$ & $486.7 \mathrm{a}$ \\
Milk production, lt/d & $13.87 \mathrm{a}$ & $14.55 \mathrm{a}$ \\
\hline
\end{tabular}

Means between columns with the same letter are not significantly different $(\mathrm{P}<0.05)$.

$M E$ metabolizable energy, $M P$ metabolizable protein, $P$ Phosphorus, $C a$ Calcium. 
Table 4. Daily nutrient intake from forages and supplements by dairy cows according to their calving to first service interval (less than or more than 50 days).

\begin{tabular}{|c|c|c|c|c|c|c|}
\hline Feeds & Group & GE, Mcal & $\mathrm{CP}, \mathrm{g}$ & $\mathrm{Ca}, \mathrm{g}$ & $\mathrm{P}, \mathrm{g}$ & NDF, $g$ \\
\hline \multicolumn{7}{|l|}{ Forages } \\
\hline \multirow[t]{2}{*}{ C. plectostachyus } & $<50 \mathrm{~d}$ & $22.8 \mathrm{~b}$ & $557 \mathrm{~b}$ & $15.9 \mathrm{~b}$ & $18.3 \mathrm{~b}$ & $3977 \mathrm{~b}$ \\
\hline & $>50 \mathrm{~d}$ & $25.9 \mathrm{a}$ & $631 \mathrm{a}$ & $18.0 \mathrm{a}$ & $20.7 \mathrm{a}$ & $4505 \mathrm{a}$ \\
\hline \multirow[t]{2}{*}{ L. leucocephala } & $<50 \mathrm{~d}$ & $9.6 \mathrm{~b}$ & $551 \mathrm{~b}$ & $28.1 \mathrm{~b}$ & $4.65 \mathrm{~b}$ & $590 \mathrm{~b}$ \\
\hline & $>50 \mathrm{~d}$ & $11.0 \mathrm{a}$ & $636 \mathrm{a}$ & $32.4 \mathrm{a}$ & $5.36 \mathrm{a}$ & $680 \mathrm{a}$ \\
\hline \multirow[t]{2}{*}{ Total from forages } & $<50 d$ & $32.4 \mathrm{~b}$ & $1108 \mathrm{~b}$ & $44.0 \mathrm{~b}$ & $22.9 \mathrm{~b}$ & $4567 b$ \\
\hline & $>50 d$ & $36.9 a$ & $1266 a$ & $50.4 a$ & $26.1 a$ & $5185 a$ \\
\hline \multicolumn{7}{|l|}{ Supplements } \\
\hline \multirow{2}{*}{ Commercial concentrate } & $<50 \mathrm{~d}$ & $11.2 \mathrm{a}$ & $463 a$ & $52.5 \mathrm{a}$ & $22.5 \mathrm{a}$ & $638 \mathrm{a}$ \\
\hline & $>50 \mathrm{~d}$ & $11.1 \mathrm{a}$ & $460 \mathrm{a}$ & $52.2 \mathrm{a}$ & $22.3 \mathrm{a}$ & $634 \mathrm{a}$ \\
\hline \multirow[t]{2}{*}{ Corn silage } & $<50 \mathrm{~d}$ & $4.8 \mathrm{a}$ & $77.2 \mathrm{a}$ & $2.24 \mathrm{a}$ & $2.20 \mathrm{a}$ & $783 \mathrm{a}$ \\
\hline & $>50 \mathrm{~d}$ & $4.4 \mathrm{a}$ & $72.0 \mathrm{a}$ & $2.08 \mathrm{a}$ & $2.10 \mathrm{a}$ & $730 \mathrm{a}$ \\
\hline \multirow[t]{2}{*}{ Rice flour } & $<50 \mathrm{~d}$ & $7.0 \mathrm{a}$ & $190 \mathrm{a}$ & $1.34 \mathrm{a}$ & $26.9 \mathrm{a}$ & $267 \mathrm{a}$ \\
\hline & $>50 \mathrm{~d}$ & $7.6 \mathrm{a}$ & $208 \mathrm{a}$ & $1.47 \mathrm{a}$ & $29.4 \mathrm{a}$ & $292 \mathrm{a}$ \\
\hline \multirow[t]{2}{*}{ Total from supplements } & $<50 d$ & $23.0 a$ & $730 a$ & $56.1 a$ & $51.6 a$ & $1687 a$ \\
\hline & $>50 d$ & $23.1 a$ & $740 a$ & $55.7 a$ & $53.9 a$ & $1655 a$ \\
\hline \multirow[t]{2}{*}{ Total diet } & $<\mathbf{5 0 d}$ & 55.4 & 1838 & 101.1 & 74.5 & 6254 \\
\hline & $>50 \mathrm{~d}$ & 60.0 & 2006 & 106.1 & 80.0 & 6840 \\
\hline
\end{tabular}

Means between rows with the same letter are not significantly different $(\mathrm{P}<0.05)$.

Cows grazing ISS were categorized according to the variable CFSI, which is indicative of the level of uterine involution and reactivation of the ovarian function (Campuzano, 2007) a parameter for which an interval of 45 days considered is ideal or adequate. Group 1 cows (CFSI $<50$ d) had a significantly lower CFSI $(39.5 \mathrm{~d})$ than group 2 cows $(83.6 \mathrm{~d})(\mathrm{P}<0.05)$, even though both intervals allow to reach the productive goal of a calf per year (Table 5). The length of the CFSI depends on the efficiency of heat detection, either by bull or farm staff. It has been suggested that this interval should be adjusted depending on cow milk production (Campuzano, 2007), prioritizing the high producing dairy cows, allowing them a longer period to recover body weight and corporal condition needed for reproductive performance.

Table 5. Reproductive performance of dairy cows grouped by calving to first service interval (less than or more than 50 days)

\begin{tabular}{llllll}
\hline Group & CFSI & DO & S/C & CI \\
\hline Group 1: less than 50 days & $39.6 \mathrm{~b}$ & $78.7 \mathrm{a}$ & $1.6 \mathrm{a}$ & $363.6 \mathrm{a}$ \\
Group 2: more than 50 days & $83.6 \mathrm{a}$ & $137.4 \mathrm{a}$ & $1.6 \mathrm{a}$ & $422.4 \mathrm{a}$ \\
\hline
\end{tabular}

Means between rows with the same letter are not significantly different $(\mathrm{P}<0.05)$

CFSI Calving to first service interval, $D O$ days open, $C I$ calving interval, $S / C$ Services per conception, (d) days.

The DO interval is a reproductive parameter useful to evaluate the reproductive behavior of the herd. Mean DO length for Colombian dairy cattle was reported to be around 181 days (Griffiths et al., 1982) and 167 days for Holstein cows (Fedegan, 2006). An acceptable interval for a dairy herd should be between 85 and 100 days (Gallego, 2009). In this study, group 1 exhibited $78.7 \pm 15.53 \mathrm{DO}$, not differing statistically to group 2 cows with $137.4 \pm 85.96$ DO $(\mathrm{P}>0.05)$ Although there were no differences between groups, due to individual marked differences (standard deviation), group 2 exceeded the ideal range of 80-90 days open. An extended DO interval can result from a negative energy balance (NEB), as occurred in group 2 at postpartum (Hashizume et al., 2002). Of all other important factors (nutritional balance, DMI, 
nutrient intake, body weight, milk production), only body condition was not measured in this study. However, body weight did not differ significantly between both groups. In this study, the protein balance was adequate for both groups (Table 3).

The calving interval (CI) are the days necessary for a cow to reproduce again. In Colombia, a 510 d CI was reported in Cebu beef cattle (Gómez, 1998). In turn, Benítez and Medina, (2001) reported that under tropical dry forest, Cebu cattle exhibited a CI of $473 \mathrm{~d}$. For beef cows, reported CI goes from $444 \mathrm{~d}$ to $550 \mathrm{~d}$ (Fedegan, 2006).

According to these reports, in a given livestock production system (dairy, beef, and double purpose) it is difficult to obtain a calf per year, which affects the herd economic performance. The CI of cows in groups 1 and 2 did not differ (363.6 and $422.4 \mathrm{~d}$; Table 5) $(\mathrm{P}>0.05)$ and cows in both groups had a significantly lower CI than those reported for Colombia, exhibiting an "ideal" CI length (Fedegan, 2006)..

Services per conception $(\mathrm{S} / \mathrm{C})$ is a very useful parameter to evaluate the reproductive performance of a bovine herd. In the US, a 33\% increment (about 0.75 services) in $\mathrm{S} / \mathrm{C}$ was reported as milk production increased (Lucy, 2001). In Colombia, Holstein cattle require 2.06 $\mathrm{S} / \mathrm{C}$ (Fedegan, 2006), yet a lower S/C value (1.6) was found for both groups in the current study.

The correlations between reproductive performance and nutritional balances are described in Table 6. The CFSI was negatively associated with $\mathrm{SC}, \mathrm{ME}, \mathrm{MP}$ and $\mathrm{Ca}(\mathrm{r}=-0.11$ to -0.64). Likewise, DO and CI were negatively correlated with dietary content of $\mathrm{ME}, \mathrm{MP}, \mathrm{Ca}$ and $P$. This indicates the importance of determining the dietary balance of $\mathrm{Ca}, \mathrm{P}, \mathrm{ME}$ and MP during the early lactation period, very poorly researched compared to the myriad of reports about deficiencies in these nutritional components during the peripartum period.

Table 6. Correlation coefficients between reproductive variables and nutritional parameters

\begin{tabular}{|c|c|c|c|c|c|c|c|c|}
\hline Parameters & CFSI & $\mathrm{DO}$ & $\mathrm{S} / \mathrm{C}$ & $\mathrm{CI}$ & $\mathrm{ME}$ & MP & $\mathrm{Ca}$ & $\mathrm{P}$ \\
\hline CFSI & 1 & & & & & & & \\
\hline DO & 0.27 & 1 & & & & & & \\
\hline $\mathrm{S} / \mathrm{C}$ & -0.11 & $0.73^{*}$ & 1 & & & & & \\
\hline $\mathrm{CI}$ & 0.27 & $1.00 * *$ & $0.73 *$ & 1 & & & & \\
\hline $\mathrm{ME}$ & -0.57 & -0.03 & 0.41 & -0.03 & 1 & & & \\
\hline MP & -0.55 & -0.03 & 0.41 & -0.03 & $0.88 * *$ & 1 & & \\
\hline $\mathrm{Ca}$ & $-0.64 *$ & -0.12 & 0.40 & -0.12 & $0.91 * *$ & $0.83 * *$ & 1 & \\
\hline $\mathrm{P}$ & -0.33 & -0.20 & 0.40 & -0.20 & $0.49 * *$ & $0.43 * *$ & $0.59 * *$ & 1 \\
\hline
\end{tabular}

* Significant correlation, $\mathrm{P}<0.05$

** Significant correlation, $\mathrm{P}<0.01$

The occurrence of NEB in group 2 could have affected the follicle growth and circulating concentrations of insulin and IGF-1, leading to lengthened calving intervals (Butler, 2000). Formulating diets to increase insulin concentration during the early lactation is a suggested way to reach the first ovulation early in the postpartum period (Gong et al., 2002). Energy intake and its reproductive effect is as well a sine qua non element of discussion because of the sensitivity of the system to subtle energy variations. All these components are possibly acting via the somatotropic axis components (including growth hormone $(\mathrm{GH})$, GH receptor, and insulin-like growth factor (IGF)-I) and nutrients partitioning.
Serum concentrations of progesterone $\left(\mathrm{P}_{4}\right)$, used to describe the cyclicity of the postpartum period, are depicted in Figure 1. Progesterone concentrations of cows in Group 1 did not differ statistically $(5,09 \mathrm{ng} / \mathrm{mL})$ from those of cows in Group $2(5.55 \mathrm{ng} / \mathrm{mL})$ along the first 24 weeks of the postpartum period $(\mathrm{P}>0.05)$. Group 1 exhibited the first ovarian cycle at week 5 in the postpartum period, whereas cows in group 2 did it at week 8. Effective service occurred around week 10 and week 16-19 for cows in Groups 1 and 2, when progesterone concentrations were 5.40 and $7.01 \mathrm{ng} / \mathrm{mL}$, respectively. Similar serum progesterone concentrations were reported in Holstein cows with early and delayed resumption 
of ovarian activity (Guáqueta et al., 2014) with early-resumption cows initiating with $2 \mathrm{ng} / \mathrm{mL}$ of progesterone and reaching around $5 \mathrm{ng} / \mathrm{mL}$, whereas late-resumption cows had $0 \mathrm{ng} / \mathrm{mL}$ of progesterone on day 20 postpartum and reached peak progesterone concentrations (about $6 \mathrm{ng} / \mathrm{mL}$ ) when they became pregnant.

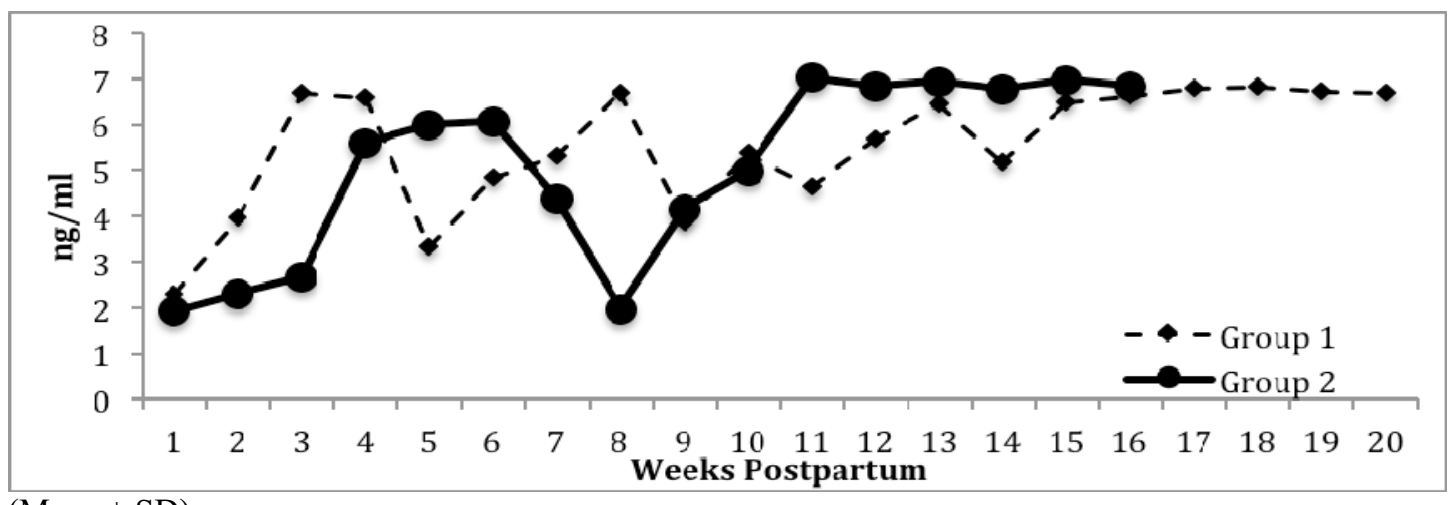

$($ Mean + SD)

Figure 1. Serum progesterone concentration patterns in dairy cows grouped by calving to first service interval (less than or more than 50 days) $(\mathrm{P}>0.05)$.

It would be advisable to evaluate diets that increase insulin levels in the postpartum period under the conditions of ISS diets as a way to prevent long CFSI. Additionally, research must be performed to evaluate the effects of mimosine and its ruminal metabolite dihydroxypyridine on the uterine environment, and herd reproductive performance. Likewise, economic evaluation of the reproductive performance of cattle in ISS and extensive management must be performed, so critical points could be identified and nutritional management recommendations could be suggested.

\section{CONCLUSIONS}

Under the conditions of this study, the ISS diet (forages plus supplements) supplied the necessary nutrients for early CFSI cows, enhancing their reproductive behavior. Cows with delayed CFSI manifested a NEB, which possibly affected their reproductive performance. However, special attention has to be placed on the balance between available ISS forages and supplements offered to animals because dietary excesses of DMI, ME, and MP could be as deleterious for reproductive performance as nutrient deficiencies.

\section{ACKNOWLEDGEMENTS}

To the Mejia Fortich Family, owners of Hacienda El Chaco. To CIPAV staff for logistical support and to COLCIENCIAS for financing the project "Research For Increasing Silvopastoral Productivity And Environmental Services In The Colombian Sustainable Livestock Project". Special thanks to the 20142015 Sustainability Strategy of the University of Antioquia, awarded to the Biogenesis Group.

\section{REFERENCES}

AGUILAR-PÉREZ, C.; KU-VERA, J.; CENTURIÓN-CASTRO, F.; GARNSWORTHY, P.C. Energy balance, milk production and reproduction in grazing crossbred cows in the tropics with and without cereal supplementation. Livest. Sci., v.122, p.227-233, 2009.

ALIMENTOS para animales: determinación del contenido de calcio, cobre, hierro, magnesio, manganeso, potasio, sodio y zinc - método usando espectrometría de absorción atómica. Bogotá: ICONTEC, 2003. (NTC 5151).

ALIMENTOS para animales: determinación del contenido de fósforo - método espectrofotométrico. Bogotá: ICONTEC, 2001. (NTC 4981).

ALIMENTOS para animales: determinación del contenido de proteína cruda - método Kjeldahl. Bogotá: ICONTEC, 1999. (NTC 4657). 
ALIMENTOS y materias primas: determinacion de los contenidos de grasa y fibra cruda. Bogotá: ICONTEC, 1973. (NTC 668). p.8.

ANIMAL feeding stuffs, animal products, and faeces or urine - determination of gross calorific value: bomb calorimeter method. Geneve: ISO, 1998. 23p. (ISO 9831).

BARAHONA, R.; SÁNCHEZ, S. Limitaciones físicas y químicas de la digestibilidad de pastos tropicales y estrategias para aumentarla. Rev. Corpoica, v.6, p.69$82,2005$.

BENÍTEZ, N.; MEDINA, N. Análisis reproductivo de un hato Brahman en el municipio de San Onofre, Sucre. 2001. 21f. Disertation (Zootecnia). Universidad de Sucre, Sucre, Bolívia.

BUTLER, W. Nutritional interactions with reproductive performance in dairy cattle. Anim. Reprod. Sci., v.60-61, p.449-57, 2000.

CAMPUZANO, R. Evaluación del período de espera voluntario en vacas especializadas en producción de leche. ResearchGate. 2007. Disponible en: $<$ http://www.fmvz.unam.mx/bovinotecnia $>$. Visitada en: 24 feb. 2015 .

CUARTAS, C.A.; NARANJO, J.F.; TARAZONA, A.M. et al. Contribution of intensive silvopastoral systems to animal performance and to adaptation and mitigation of climate change. Rev. Colomb. Cienc. Pec., v.27, p.76-94, 2014.

DETERMINATION of ash in animal feed. In: OFFICIAL methods of analysis. 18.ed. Oma: AOAC, 2005. (Official method 942.05). p.8.

EL-HARITH, E.; MOHME, H.; TER-MEULEN, U. et $a l$. A method for large scale extraction of mimosine. $J$. Anim. Physiol. Anim. Nutr., v.57, p.105, 1987.

GALLEGO, M.I. (Ed.). Manejo del problema reproductivo en ganado de leche. Colombia: Universidad de Ciencias Aplicadas y Ambientales, 2009. 221p.

GARCÍA, D.; WENCOMO, H.; GONZÁLEZ, M. et al. Caracterización de diez cultivares forrajeros de Leucaena leucocephala basada en la composición química y la degradabilidad ruminal. Rev. Med. Vet. Zootec., v.13, p.1294-1303, 2008.

GÓMEZ, M. Influencia del tamaño en la efíciencia reproductiva y productiva de la vaca Brahman en el trópico. Rev. Cebú, v.304, p.42-52, 1998.

GONG, J.; LEE, W.; GARNSWORTHY, P. et al. Effect of dietary-induced increases in circulating insulin concentrations during the early postpartum period on reproductive function in dairy cows. Reproduction, v.123, p.419-427, 2002.
GRIFFITHS, I.; GALLEGO, M.I.; VILLAMIL, L.C. Factores de infertilidad y pérdidas económicas en ganado de leche en Colombia. [Bogotá]: ICA, 1982. $168 \mathrm{p}$.

GUÁQUETA, H.; ZAMBRANO, J.; JIMÉNEZ, C. Factores que afectan la reactivación ovárica postparto en vacas Holstein, en el trópico alto. Rev. Med. Vet. Zootec., v.19, p.3970-3983, 2014.

HAMMOND, A. Leucaena toxicosis and its control in ruminants. J. Anim. Sci., v.73, p.1487-1492, 1995.

HASHIZUME, T.; KUMAHARA, A.; FUJINO, M. et al. Insuline-like-growth factor I enhances gonadotropin-releasing hormone - stimulated luteinizing hormone release from bovine anterior pituitary cells. Anim. Reprod. Sci., v.70, p.13-21, 2002.

HOLDRIDGE, L.; GRENKE, W.; HATHEWAY, T. et al. (Eds.). Forest environments in tropical life zones, a pilot study. Oxford: Elsevier Science, 1971. $747 \mathrm{p}$.

LA VISIÓN de Corpoica para el mejoramiento del hato bovino nacional. Corpoica: Fedegan, 2006. 33p.

LUCY, M. Reproductive loss in high-producing dairy cattle: where will it end? J. Dairy. Sci., v.84, p.12771293, 2001.

MARTINS-MAURÍCIO, R.; FERNANDES-SOUSA, L.; LIMA-FERREIRA, A. et al. Alimentaçao de bovinos leiteiros em sistemas silvipastoris. In: (Eds.). GONÇALVES, L.C.; BORGES, I.; FERREIRA, P.D.S. Alimentação de gado de leite. Belo Horizonte: FEPMVZ, 2009. p.268-303.

MONTAÑO, E.; RUIZ-CORTÉS, Z. ¿Por qué no ovulan los primeros folículos dominantes de las vacas cebú posparto en el trópico colombiano? Rev. Colomb. Cienc. Pec., v.18, p.127-135, 2005.

NUTRIENT requirements of dairy cattle. Washington: National Academy Press, 2001. 381p.

ROCHE, J.R.A.; BURKE, C.R.A.; MEIER, S.A. et al. Nutrition $\mathrm{x}$ reproduction interaction in pasture-based systems: is nutrition a factor in reproductive failure? Anim. Prod. Sci., v.51, p.1045-1066, 2011.

SIERRA-MONTOYA, E.; CHARÁ, J.D.; BARAHONA-ROSALES, R. The nutritional balance of recently calved and early lactation dairy cows grazing in intensive silvopastoral systems under tropical dry forest of Colombia. 2015. [In press].

TARAZONA, M.A.M.; CEBALLOS, B.M.C.; CUARTAS, C.C.A. et al. The relationship between nutritional status and bovine welfare associated to adoption of intensive silvopastoral systems in tropical conditions. Rome: FAO, 2013. p.69-78. 